RJOAS, 4(52), April 2016

DOI http://dx.doi.org/10.18551/rjoas.2016-04.09

\title{
THE PROPENSITY OF FINAL YEAR UNDERGRADUATE AGRICULTURE STUDENTS TO BECOME AGRICULTURAL ENTREPRENEURS: IMPLICATIONS FOR FOOD SELF- SUFFICIENCY IN NIGERIA
}

\author{
Akintayo Oluremi ${ }^{*}$ \\ Institute of Agricultural Research and Training, Moor Plantation, Ibadan, Nigeria \\ Adediran Tolulope \\ Federal College of Agriculture, Ibadan, Nigeria \\ *E-mail: oluremijayakint@gmail.com
}

\begin{abstract}
This study examined the factors influencing the willingness of final year undergraduate agriculture students to become agricultural entrepreneurs after graduation using a sample of final year agricultural students in four tertiary institutions in south-west Nigeria. Data were obtained through structured questionnaire. Results indicate that fifty-one percent of the students had aspirations for other things apart from agriculture as a profession after graduation. Reasons given for lack of interest in the practice of agriculture include inaccessible agricultural funds, labour-intensive nature of farming in the country and perceived low profitability of agricultural enterprises. Factors which had significant effects on the probability that a final year agricultural student would become an agricultural entrepreneur after graduation include the first choice course on admission to tertiary institution, parents' level of education and the person who made the final decision for a student to study agriculture in the tertiary institution. Students who had agriculture as the first choice course during admission into tertiary institution are more (0.78) likely to become entrepreneurs in agriculture after graduation. Students whose parent/parents had tertiary education are (0.59) less likely to become agricultural entrepreneurs. Students who personally made the decision to study agriculture are (0.78) less likely to become agricultural entrepreneurs. This implies that the students are not good decision makers in relation to career choice and thus need guidance when choosing their course of study. This will ensure that only interested students study agriculture with a view of becoming agricultural entrepreneurs after graduation thus helping the nation attain food self-sufficiency.
\end{abstract}

\section{KEY WORDS}

Agricultural entrepreneurs, discrete choice model, food self-sufficiency.

Nigeria, the most populous country in West Africa with an estimated population of 181 million (CIA, 2015) lies between latitudes $4^{\circ}$ and $14^{\circ}$ north of the equator and longitudes $3^{0}$ and $14^{0}$ east of the Greenwich meridian. The country lies wholly within the tropics with highly diversified agro-ecological condition and great potential for a wide range of agricultural production (Manyong et al, 2005). Although the oil and gas sector of the economy contributes almost ninety-nine per cent exports, it contributes only about four per cent to employment. On the other hand, agriculture contributes $0.2 \%$ of total exports and employs between sixty-five and seventy per cent of the national workforce. Nigeria can thus be considered as an agrarian nation. The country has a land area of 92.4 million hectares out of which about ninety per cent (84 million hectares) is good for agriculture (Philip et al, 2009). Out of the 84 million hectares however, only about forty per cent is currently cultivated. The country also has about two hundred and thirty billion cubic metres of water. Despite Nigeria's rich agricultural resource endowment, there is shortfall in domestic food production which has given rise to massive food 
importation in order to meet national food demand. Nigeria is thus presently a net food importer, spending about 4.35billion US dollars on food import in 2013 (Natsa, 2014).

The most fundamental constraint to sustainable agricultural growth and development in Nigeria has been identified to be the peasant nature of the production system (Manyong et al, 2005; Philip et al, 2009) which consists of small holder farmers who account for more than $70 \%$ of national farming population and cultivate less than 5 hectares per capita (Phillip et al, 2009).

Nevertheless, Nigeria can presently be said to be on the path to putting agriculture back in its position of preeminence. This is evident through several policies and initiatives that have been put in place by the government in order to develop and transform the agricultural sector. These include the presidential initiatives on rice, cassava, vegetable oil, tree crops, livestock, fisheries and aquaculture as well as the Agricultural Transformation Action Plan (ATAP) which is focused on the development of value chain of specific commodities and promotion of value addition along the commodity chain.

Considering demographic issues, data indicate that young people constitute a high proportion of the Nigerian population, with 52.2 million of the country's population currently between the ages of 18 and 35 years (NBS and FMYD, 2013). Nigeria thus has a large youthful population of which about seventy per cent, unfortunately is unemployed. Nevertheless, young people have been identified as the greatest natural resource base of the country (Kakwagh and Ikwuba, 2010). Evidence also shows that the ageing of the rural farming population is resulting in lower per capita productivity and output (Adebo and Sekumade, 2013). This calls for concern as most of the rural youth who could take over farming have migrated to urban areas. These youth have chosen not to pursue livelihoods as farmers. The importance of youth succeeding the ageing farming population can not be over emphasized and would depend on the positive attitudes and willingness of the youths towards taking up agriculture as a career/profession.

Adewale et al (2005) noted that there is an apparent shift in interest from agriculture to other specializations such as medical sciences, engineering, pharmacy, teaching, and accountancy among Nigerian youth. This is due to the notion that agriculture, particularly farming, is a 'low-status' job meant for people who are not qualified for white-collar jobs. In other words, agriculture is still viewed as non professional and as such, a non profitable career option for young people, especially graduates. It is quite often viewed as a dead-end career that involves life-long labour on a farm (The guardian, 2014).

For sustainable agricultural growth and development, there is need to get the youth involved in farming and agribusiness as their ideas and manpower are very important. Education is the springboard for sustainable agricultural growth and development. It has been asserted that capacity building through formal agricultural education is required for the production of skilled manpower to function optimally in several areas of the agricultural sector (Ramdwar and Ganpat, 2010). Thus, the participation of agricultural graduates in farming and agribusiness is very important for the growth and development of the sector in Nigeria. It has been noted that aspirations play a significant role in influencing how young people think, how they feel about themselves and how they make life choices (Schaefer and Meece, 2009). Also, aspirations are formed and develop in response to various circumstances and are adapted and changed in light of new experiences, information and choices (Leavy and Smith, 2010). Thus, the aspirations of youth who have studied agriculture in tertiary institutions are important and should be of interest in agricultural development and policy formulation in the country.

There are currently more than twenty-six agricultural based monotechnics in addition to several agricultural based research institutes and over one hundred and ten universities (federal, state and private owned) in Nigeria producing thousands of graduates every year. It is expected that the agriculture graduates from these tertiary institutions would practice agriculture as a business for the transformation of the Nigerian agriculture sector, bringing about national food self sufficiency and agricultural exports. In reality, there are sufficient numbers of people with agricultural training qualifications, but the issue of low performance of the agricultural sector 
in meeting national food demand gives room for great concern. With a country like Nigeria which has a vast natural resource endowment and so much human capital, agricultural development should be very advanced through agricultural entrepreneurship. Entrepreneurship has been identified as a process of starting a business offering an innovative product, process or service while an entrepreneur can be defined as a person who organizes or operates a business (Wikipedia, 2015). Kahan (2012) viewed entrepreneurship as a key factor for agricultural development in an ever-changing and increasingly complex global economy.

The main objective of the study is to determine the factors responsible for career choice among final year agriculture students in south west Nigeria and examine their willingness to continue in an agricultural career as entrepreneurs after graduation.

\section{METHODOLOGY OF RESEARCH}

The sampling procedure employed was the multi-stage sampling technique. The first stage was the random selection of three states from the six states in southwest Nigeria while the second sampling stage involved the random selection of four institutions from the compiled list of universities of the selected states. The population for the study included all final year agriculture students in the selected institutions. Final year students were purposively selected for the study because this group of students were about to make actual choices in entering the workforce. A random sample of sixty students was drawn from each institution and primary data were collected through the use of pre-tested structured questionnaire.

Analysis of data was carried out using descriptive and inferential statistics. The study also employed the discrete choice model whose fundamental pillar of analysis is the model for binary choice (Greene, 2008).

In this study, the binary choice is for final year agricultural students to practice agriculture after graduation or not. Not to take up agriculture after graduation means engaging in non-agriculture activity.

\section{RESULTS AND DISCUSSION}

Socio-demographic characteristics of respondents: The average age of the students was 22.43 years. Fifty-two per cent $(52.08 \%)$ of the students were males while $47.92 \%$ were females. About ninety-six per cent $(96.67 \%)$ of the sampled students were unmarried while only $3.33 \%$ were married. About nine per cent $(9.17 \%)$ of the students were self-sponsored for their tertiary education, $87.92 \%$ were sponsored by their parents while $2.91 \%$ were sponsored by people other than their parents. With regard to their parents' occupation, at least one of the two parents had a tertiary education for $43.33 \%$ of the total sampled students.

The range of agricultural courses studied by the sampled students included animal science, agronomy, forestry, agricultural extension and agricultural engineering.

The choice of agriculture as a course of study: In relation to first choice course of the sampled students, more than half $(55.00 \%)$ had agriculture-related courses as their first choice during their admission into the tertiary institution while others $(45.00 \%)$ had other course option preferences such as nursing, law, medicine, banking/accounting, chemical engineering, electrical engineering, computer science, biochemistry, petroleum engineering, civil engineering mechanical engineering and physiotherapy as first choice during their admission into the institution. The latter group of students however ended up studying agriculture for reasons which include difficulty in obtaining admission to study the course of their first choice. Thus, these students study agriculture as a second, third or even last choice option. The reasons given by the sampled students for choosing to study agriculture in the tertiary institution are summarized in Table 1. 
Table 1 - Reasons for studying agriculture as a course

\begin{tabular}{|c|c|c|}
\hline Reasons & frequency & $\%$ \\
\hline Self employment after school & 99 & 41.25 \\
\hline Interest in the course & 80 & 33.33 \\
\hline No admission to other courses & 61 & 25.42 \\
\hline Total & 240 & 100.00 \\
\hline
\end{tabular}

The students who indicated that they chose to study agriculture in order to become self employed after graduation emphasized the fact that they would like to be financially independent as they foresee entrepreneurship in agriculture as a means to achieve that goal. Twenty-five per cent of the students indicated they chose to study agriculture because they had not been able to gain admission into a tertiary institution for their preferred first choice course, hence agriculture became a last resort to obtain degree or as a stepping stone to their preferred course option. However, thirty-three per cent of the sampled students simply indicated interest as the reason for their choice of agriculture as the first choice course of study at the tertiary level.

The final decision to study agriculture was taken by the parent for only $14.58 \%$ of the sampled students while the decision to study agriculture was made by eighty per cent of the students themselves and the remaining five per cent $(5.42 \%)$ of the students had the decision taken for them by friends and relatives. This result implies that parents make the career choice for a small percentage of agricultural students.

It is of interest to note that of the students who studied agriculture as a first choice course, $93.33 \%$ took the decision themselves while parents made the decision for $6.67 \%$.

Willingness to become entrepreneurs in agriculture after graduation: Out of the total sampled students, $48.75 \%$ indicated willingness to practice agriculture after graduation while $51.25 \%$ indicated interest in non-agriculture activities such as going for postgraduate studies, going to the university to study another course apart from agriculture or going into banking profession. This finding is similar to that of Adebo and Sekumade (2013) who found that fortyeight per cent (48.3\%) of agricultural students in a state owned university located in south west Nigeria considered studying agriculture a stepping stone to other careers. Furthermore, out of the students who chose agriculture as their first option course during admission into their institutions, $81.06 \%$ indicated willingness to practice agriculture after graduation. This result implies that the national goal of food self-sufficiency is left to be attained by a small proportion of the skilled agricultural graduates who would eventually take up agriculture as a profession after graduation. This also points to the fact that only a small proportion of potential agricultural professionals actually end up in the practice of agriculture after graduation from their tertiary institutions. This means that the nation is endowed with the required human capital to attain food self-sufficiency but there is need to harness such human resource towards the achievement of the goal.

Several factors have the potential of influencing the choice of a profession/career of a student. These factors include gender, personal interest (Kochung and Migunde, 2011), environment (context in which the students live), parents' educational background (Borchert, 2002), parents' occupation (Trice, 1991), family size (Downey, 1995).

As shown in Table 2, the sex and family position of student as well as number of children in the family showed no significant effect on the probability of the student choosing to be an agricultural entrepreneur after graduation. In addition, the possession of a personal or family farm did not have significant effect on the choice of a student becoming an agricultural entrepreneur after graduation.

The person who made the final decision for a student to study agriculture in the tertiary institution had a significant effect on the probability of the student becoming an agricultural entrepreneur after graduation. The result indicates that students who personally made the 
decision to study agriculture are (0.78) less likely to become entrepreneurs in agriculture after graduation. This implies that the students on their own are not good decision makers in relation to career choice and thus need to be guided when it comes to choosing their course of study in tertiary institutions. Furthermore, students who had agriculture as the first choice course during admission into tertiary institution are more (0.78) likely to become entrepreneurs in agriculture after graduation. This is not surprising as it is expected that a first choice course would be the one for which a student has interest and to some extent, has some passion for in order for him/her to pursue formal education in agriculture.

Table 2 - Probit regression result

\begin{tabular}{|l|l|l|l|}
\hline \multicolumn{1}{|c|}{ Variables } & \multicolumn{1}{|c|}{ Coefficient } & \multicolumn{1}{c|}{$\mathrm{z}$} & \multicolumn{1}{c|}{$\mathrm{P}>\mid \mathrm{z}$} \\
\hline Sex & .312153 & 1.23 & 0.220 \\
\hline Fampostn & .1064879 & 1.29 & 0.197 \\
\hline Totchdrn & -.0228942 & -0.30 & 0.764 \\
\hline Cosdetm & -.7828861 & -2.10 & 0.035 \\
\hline Entcos & .7856563 & 2.64 & 0.008 \\
\hline havfarm & .1857042 & 0.69 & 0.491 \\
\hline Parntedu & -.5884363 & -2.26 & 0.024 \\
\hline Constant & -.026568 & -0.05 & 0.961 \\
\hline LR chi2(7) & 19.22 & & \\
\hline Prob $>$ chi2 & 0.0075 & & \\
\hline
\end{tabular}

Where: fampostn = family position of student (for example $1^{\text {st }}$ child, $2^{\text {nd }}$ child, last child); totchdrn = total number of children in the family; cosdetm = person who determined student's course of study; entcos = entry course of student into tertiary institution; havfarm $=$ whether or not a student has a personal farm; parntedu = parent's tertiary education. Likelihood ratio with a $\rho$-value of 0.0075 indicates that the model as a whole is statistically significant.

Parents' education also had significant effect on the probability that their child/children would become agricultural entrepreneur after graduation. Students whose parent/parents had tertiary education are (0.59) less likely to become agricultural entrepreneurs after graduation. Thus, the probability of the $43.33 \%$ of the sampled students who had one or both parents with a tertiary education to continue with an agriculture career after graduation is only 0.41 .

\section{CONCLUSION AND IMPLICATIONS}

The importance of food self-sufficiency for a nation cannot be over-emphasized. This of course, is the extent to which the nation can satisfy her food needs entirely from domestic production (Thomson and Metz, 1998) using only domestic resources.

It is clear from the study that not all students who study agriculture at the tertiary level of education are committed to taking agriculture as a profession after graduation. Some of the students had aspirations towards taking up careers other than those in the field of agriculture. Three main factors were found to influence the propensity of the final year students to become entrepreneurs in agriculture after graduation. These are the first choice course during admission into the tertiary institution (This is closely linked with student's interest in the course); person who determined the choice of agriculture as the course to be studied by the student; and parental level of education. There is therefore need for intervention at the government and institutional levels to enlighten students before admission into tertiary institutions on the prospects and importance of agriculture and related courses as a profession. This will help to streamline those who study agriculture to those who are genuinely interested in becoming agricultural entrepreneurs after graduation. With the knowledge and skills acquired from school, their contributions to the agricultural sector would actually move the sector to a vibrant, modern one and take the nation to a food self-sufficient position. 


\section{REFERENCES}

1. Adebo, G. M and Sekumade, A. B. (2013). Determinants of career choice of agricultural profession among the students of the faculty of agricultural sciences in Ekiti state university, Nigeria. Journal of agricultural extension and rural development 5(11):249-255.

2. Adewale, J. G., Oladejo, J. A. and Oguniyi, L. T. (2005). Economic contribution of farm children to agricultural production in Nigeria: A case study of Ekiti State of Nigeria. Journal of social sciences 10(2):149-152.

3. Borchert, M. (2002). Career choice factors of high school students. A research paper submitted in partial fulfillments of the requirements for the master of science degree in career and technical education to the graduate college, university of Wisconsin-stout, USA. $82 \mathrm{pp}$.

4. CIA (Central Intelligence Agency). (2015). World fact book. www.cia.gov/library, accessed August 4, 2015.

5. Downey, D. B. (1995). When bigger is not better: Family size, parental resources, and children's educational performance. American sociological review 60:746-761.

6. Thomsom Anne and Metz Manfred (1998). Implications of economic policy for food security: A training manual. www.fao.org/docrep/004/x3936e/, accessed December 15, 2015.

7. Greene, W. (2008). Discrete choice modeling in 'The handbook of econometrics' Volume 2. Applied econometrics part 4.2. ed T. Mills and K. Patterson. Palgrave, London.

8. Kahan, D. (2012). Entrepreneurship in farming. Food and Agriculture Organization of the United Nations, Rome. www.fao.org/publications, accessed September 2, 2015.

9. Kakwagh, V. V. and Ikwuba, A. (2010). Youth unemployment in Nigeria: Causes and related issues. Canadian social science 6(4):231-237.

10. Kochung, E and Migunde, Q. (2011). Factors influencing students career choices among secondary school students in Kisumu municipality, Kenya. Journal of emerging trends in educational research and policy studies 2(2):81-87.

11. Leavy, J and Smith, S. (2010). Future farmers: Youth aspirations, expectations and life choices. Discussion paper 013. Future Agricultures. www.future-agricultures.org, accessed June 12, 2012.

12. Manyong, V. M., Ikpi, A., Olayemi, J. K., Yusuf, S. A., Omonona, B. T., Okoruwa, V. and Idachaba, F. S. (2005). Agriculture in Nigeria: Identifying opportunities for increased commercialization and investment. IITA (International Institute for Tropical Agriculture), Ibadan, Nigeria. 159pp.

13. Natsa, R. T. (2014). Food import bill drops by $\$ 2.6 b n$ in 3 years. http://leadership.ng/news/377812/food-import-bill-drops, accessed August 17, 2015.

14. NBS and FMYD (National Bureau of Statistics and Federal Ministry of Youth Development) (2013). 2012 National baseline youth survey: Final report. 146pp. www.nigerianstat.gov.ng , accessed July 17, 2015.

15. Philip, D., Nkonya, E., Pender, J., and Oni, O. A. (2009). Constraints to increasing agricultural productivity in Nigeria: A review. Nigeria Strategy Support Program (NSSP), Background paper 6. IFPRI (International Food Policy Research Institute), Washington, DC.

16. Ramdwar, M. N. A. and Ganpat, W. G. (2010). Likelihood of students in the formal education system in Trinidad to pursue agriculture as a profession and its implications for development. Journal of agricultural education 51(4):28-37.

17. The Guardian. (2014). How to inspire a generation of farming entrepreneurs. www.theguardian.com/global-development-professionals-network/2014/, November 14, 2015.

18. Trice, A. D. (1991). Stability of children's career aspirations. The journal of genetic psychology 152:137-139.

19. Wikipedia (2015). https://en.wikipedia.org/wiki/Entrepreneurship, accessed August 25, 2015. 